\title{
SCREENING FOR SWEET POTATO (Ipomoea Batatas L.) LEAF CURL VIRUS (SPLCV) AND ITS ELIMINATION USING THERMOTHERAPY-MERISTEM TIP CULTURE TECHNIQUE
}

\author{
E. Arkorful ${ }^{1}$, A. S. Appiah ${ }^{1}$ and H. Dzahini-Obiatey ${ }^{2}$
}

ABSTRACT

\begin{abstract}
Despite its high potential for food security, production of sweet potato (Ipomoea batatas L.) is constrained by viruses which reduce yield by $90 \%$. It is, therefore, essential to detect and eliminate these viruses in elite clones before dissemination to farmers. In this study, we used visual symptomatology and polymerase chain reaction (PCR) techniques to detect Sweet potato leaf curl virus (SPLCV) and eliminated the virus using thermotherapy-meristem tip culture. Visual symptomatology revealed virus associated symptoms, including vein clearing, interveinal chlorosis, chlorotic spots, upward leaf curling, leaf narrowing, purpling, blistering and leafyellowing in all 22 accessions grown on the field. The disease incidence varied between accessions with US003 having the lowest (20\%), while ten accessions had the highest (90\%). The severely diseased accessions were tested for SPLCV using PCR technique. The technique detected the virus in $30 \%$ of the accessions. Plants that tested positive to PCR assay were grown in the chamber at $35^{\circ} \mathrm{C}$ for 4 weeks followed by meristem culture. The regenerants were indexed for SPLCV. Fifty-two percent (52.4\%) of the regenerants were successfully cleaned of the virus. Virus indexing and elimination will enhance the dissemination of disease-free planting materials to farmers.
\end{abstract}

Key words: Ipomoea batatas, PCR, thermotherapy, meristem culture.

\section{INTRODUCTION}

Sweet potato (Ipomoea batatas L.) is a major food security crop worldwide (Woolfe, 1992). It is an early maturing crop and grows well on marginal soils. The importance of the crop will even be more significant in the wake of climate change and its associated drought and emergence of new pests and diseases (Opiyo et al., 2010). However, the production of the crop is constrained by several biotic and abiotic factors. Virus diseases rank second to weevil in causing significant yield reduction in sweet potato (Ndunguru and Kapinga, 2007). Most sweet potato viruses express themselves visually (are symptomatic) as vein clearing, interveinal chlorosis, chlorotic mosaic, leaf curling, stunted growth, leaf narrowing and distortion (Fuentes, 2010).

The detection and identification of sweet potato viruses remains a difficult procedure and this is complicated by frequent occurrence of mixed infections and synergistic complexes (Tairo et al., 2004). However, several virus detection methods such as visual observation, enzymelinked immunosorbent assay (ELISA), polymerase chain reaction (PCR) and its variant reverse-transcription polymerase chain reaction (RT-PCR) have been used for virus indexing in sweet potato (Ghosh and Aglave, 2007). Of all the detection methods, PCR with its variant RT-PCR is the most sensitive and reliable (Opiyo et al., 2010).

Owing to the high yield losses caused by viral diseases on sweet potato, their elimination from planting materials is essential for sustainable production of the crop. Since these viral diseases are spread simultaneously via traditional planting of vines, alternative methods of planting material production aimed at both virus elimination and rapid multiplication should be exploited. One of the

\footnotetext{
${ }^{1}$ Biotechnology and Nuclear Agriculture Research Institute (B.N.A.R.I.), Ghana Atomic Energy Commission 1 (G.A.E.C.), Atomic Post Office, Kwabenya-Accra.

${ }^{2}$ Department of Plant Pathology, Cocoa Research Institute Ghana (C.R.I.G.), P. O. Box 8, New Tafo-Akim, Ghana.
} 
most effective techniques which would achieve this dual objective is micropropagation via thermotherapy-meristem culture (El Far and Ashoub, 2009) which is made possible by cell totipotency. The efficiency of virus eradication depends on several factors including pretreatment in heat chamber, size of explants, virus titre in explants, as well as its genotype (Wang et al., 2008). Thermotherapy disrupts viral ssRNA and dsRNA synthesis, thereby, reducing virus population in host plants $(\mathrm{Qu}$ et al., 2005). El Far and Ashoub (2009) used meristem culture coupled with thermotherapy to obtain $100 \%$ virus-free sweet potato in Egypt; thus, this technique has been found effective in virus elimination in sweet potato. In addition to systemic virus elimination for distribution to farmers as a basis of a guaranteed disease-free stock for further propagation, thermotherapy-meristem culture technique can be used for rapid multiplication of elite clones for in vitro conservation either via slow growth or cryopreservation. On this account, we employed visual symptomatology and PCR techniques to detect Sweet potato leaf curl virus in 22 accessions of sweet potato and their elimination using thermotherapy coupled with meristem-tip culture technique.

\section{MATERIALS AND METHODS}

\section{Planting materials}

Twenty-two accessions of sweet potato, namely VOTCR002, VOTCR003, VOTCR004, VOTVR009, BOT02020, ВОT03020, ВОТ03028, ВОT0320, UE005, UE007, UE009, UE014, UE017, US001, US002, US003, Histarch, CRI027, CRI054, JON001, SA-BNARI and UK-BNARI were used in the present study. Fresh vine cuttings with five nodes per cutting were planted on ridges with three replicates using randomised complete block design (RCBD).

\section{Virus indexing by visual observation and PCR technique}

At eight weeks after planting, plants were indexed for virus infection and this was done weekly for six weeks using visual observation of disease symptoms on young fresh leaves to estimate disease incidence (DI) using the method described by Njock and Ndip 2007 as:

Disease incidence, $\mathrm{DI}=(\mathrm{z}-\mathrm{y} / \mathrm{z}) \times 100$

Where $\mathrm{Y}$ is number of diseased plants; $\mathrm{Z}$ is total number of plants.

Ten accessions which showed comparatively high disease incidence on the field were screened for SPLCV using polymerase chain reaction (PCR) technique. Genomic deoxyribonucleic acid (DNA) was extracted using Sodium hydroxide $(\mathrm{NaOH})$ extraction method as described by Wang et al. (1993). A hundred (100) $\mathrm{mg}$ of fresh young leaves was finely ground in $400 \mu \mathrm{L}$ of $0.5 \mathrm{M} \mathrm{NaOH}$ using pestle and mortar. The solution was poured into a clean $2 \mathrm{ml}$ eppendorf tube and centrifuged at $14000 \mathrm{rpm}$ for $5 \mathrm{~min}$. The supernatant was transferred to a new eppendorf tube and five (5) $\mu \mathrm{L}$ of it was added to $495 \mu \mathrm{L}$ of $100 \mathrm{mM}$ Tris $\mathrm{HCl}(\mathrm{pH} 8.0)$ to obtain genomic DNA and amplified. The DNA amplification was performed in $20 \mu \mathrm{L}$ reaction volumes using degenerate geminivirus primer pair SPG1/ SPG2 and Sweet potato leaf curl virus strainspecific primer pair SPG3/SPG4. The reaction mixture for degenerate geminivirus detection contained $8.4 \mu \mathrm{L}$ of PCR water, $4.0 \mu \mathrm{L}$ of $5 \mathrm{x}$ Taq buffer, $2.8 \mu \mathrm{L}$ of $25 \mathrm{mM} \mathrm{MgCl}, 0.5 \mu \mathrm{L}$ of $10 \mathrm{mM}$ dNTPs, $1.0 \mu \mathrm{L}$ of $10 \mathrm{mM}$ SPG1 (forward primer), $1.5 \mu \mathrm{L}$ of $10 \mathrm{mM}$ SPG2 (reverse primer) (Lotrakul et al., 1998), 0.3 $\mu \mathrm{L}$ of $0.09 \mathrm{U}$ Taq DNA polymerase and $1.5 \mu \mathrm{L}$ of $11.06 \mu \mathrm{g} / \mathrm{ml}$ genomic DNA. For detection of Sweet potato leaf curl virus, the reaction mixture contained $8.8 \mu \mathrm{L}$ of PCR water, 4.0 $\mu \mathrm{L}$ of $5 \mathrm{x}$ Taq buffer, $2.8 \mu \mathrm{L}$ of $25 \mathrm{mM} \mathrm{MgCl}_{2}$, $0.5 \mu \mathrm{L}$ of $10 \mathrm{mM}$ dNTPs, $1.0 \mu \mathrm{L}$ each of $10 \mathrm{mM}$ SPG3 (forward) and $10 \mathrm{mM} \mathrm{SPG} 4$ 
(reverse) primers (Lotrakul et al., 1998), 0.3 $\mu \mathrm{L}$ of $0.09 \mathrm{U}$ Taq DNA polymerase and $1.6 \mu \mathrm{L}$ of $11.06 \mu \mathrm{g} / \mathrm{ml}$ genomic DNA. The touchdown PCR amplification conditions used involved 11 cycles of initial denaturation of $94{ }^{\circ} \mathrm{C}$ for $40 \mathrm{~s}, 61^{\circ} \mathrm{C}$ for $30 \mathrm{~s}$ and $72{ }^{\circ} \mathrm{C}$ for $90 \mathrm{~s}, 24$ cycles of denaturation at $94^{\circ} \mathrm{C}$ for $40 \mathrm{~s}$, primer annealing at $60{ }^{\circ} \mathrm{C}$ for $40 \mathrm{~s}$ and elongation at $72{ }^{\circ} \mathrm{C}$ for $90 \mathrm{~s}$. The final elongation was done at $72{ }^{\circ} \mathrm{C}$ for $10 \mathrm{~min}$. The PCR products were electrophoresed on $1 \%$ agarose solution $(\mathrm{w} / \mathrm{v})$ at a constant voltage of 90 Volts for $45 \mathrm{~min}$ and autoradiographed.

\section{Thermotherapy coupled with meristem tip culture}

Vine cuttings from sweet potato accessions that showed high disease incidence on the field and also tested positive to PCR assay were subjected to thermotherapy at $35{ }^{\circ} \mathrm{C}$ for 4 weeks and replicated fifteen times. The emerging shoots were used as source of explants for shoots initiation via meristem culture.

The culture medium prepared was Murashige and Skoog (MS) (1962) basal medium supplemented with $30 \mathrm{~g} / \mathrm{L}$ sucrose, 1.0 $\mathrm{mg} / \mathrm{L}$ thiamine- $\mathrm{HCl}, \quad 1.0 \mathrm{mg} / \mathrm{L}$ nicotinic acid, $\quad 1.0 \mathrm{mg} / \mathrm{L}$ pyridoxine- $\mathrm{HCl}, \quad 2.0$ $\mathrm{mg} / \mathrm{L}$ glycine and $100 \mathrm{mg} / \mathrm{L}$ myo-inisitol (initiation medium). Shoot elongation and development medium was prepared from basal MS medium supplemented with 0.25 $\mathrm{mg} / \mathrm{L}$ 6-benzylaminopurine (BAP), $0.1 \mathrm{mg} / \mathrm{L}$ $\alpha$-naphthaline acetic acid (NAA) and $0.1 \mathrm{mg} / \mathrm{L}$ gibberellic acid (GA ). The $\mathrm{pH}$ of all media was adjusted to 5.8 prior to the addition of $3.5 \mathrm{~g} / \mathrm{L}$ phytagel and autoclaved. The explants were excised, sterilized and cultured using the method described by International Potato Center (CIP). The initiated cultures were kept in a growth room with a photoperiod of 16 hour light and 8 hour darkness and a light intensity of 2700 lux at a temperature of 27 $\pm 2{ }^{\circ} \mathrm{C}$. After 30 days of culture, emerging shoots were transferred to MS basal medium for shoot development and elongation for six weeks. PCR technique was employed for the virus detection in regenerated shoots to confirm elimination of virus.

\section{RESULTS AND DISCUSSION}

\section{Viral disease incidence (DI) on sweet potato accessions on the field}

The sweet potato cuttings sprouted within one week after planting, and by the eighth week, all the accessions showed varied degrees of visual symptoms on the field ranging from mild to severe, depending on the accession (Fig. 01 and 02); thus, degree of viral disease incidence was taken. The symptoms observed were vein clearing, interveinal chlorosis and chlorotic spots, upward curling on leaf edges, leaf narrowing and distortion, purpling, leaf blistering, reduction of the leaf blades and general yellowing of the entire plant. All the symptoms were observed on the entire field, except for leaf curling which was localised only on accessions UK-BNARI and UE007 in replication one.

Viral disease incidence varied from 10 to 90 $\%$ (Fig. 01 and 02 ) indicating mild to severe disease incidence. This could be due to several factors such as virus concentration in the vine cuttings used as planting materials and the genetic constitution of the individual accessions. At 8 weeks after planting, three accessions namely BOT03028, VOTCR003 and US003 showed mild disease incidence (DI) of 15,10 and $15 \%$ respectively, while seven accessions BOT0320, UE009, US002, HISTARCH, VOTCR004, VOTVR009 and US001 showed severe DI of 80, 75, 90, 80, 75,75 and $70 \%$ respectively. The remaining twelve accessions showed moderate (mean of $49.17 \%$ ) incidence (Fig. 01). In spite of this varied observations, there was no significant difference $(p \geq 0.05)$ in disease incidence between all accessions. The mean DI values of $53.41 \%$ at the eighth week indicating the 
presence of the virus at that early stage could is by-far the major means of propagation of be due to the presence of the viral particles sweet potato. A mean disease incidence of in the vines used as planting materials. It is $64.55 \%$ has been reported by Ndunguru et generally known that in most vegetatively al. (2009) in sweet potato grown in Central propagated crops such as sweet potato, virus Uganda, and this compares favourably with transmission is mostly through cuttings, which the report in this work.

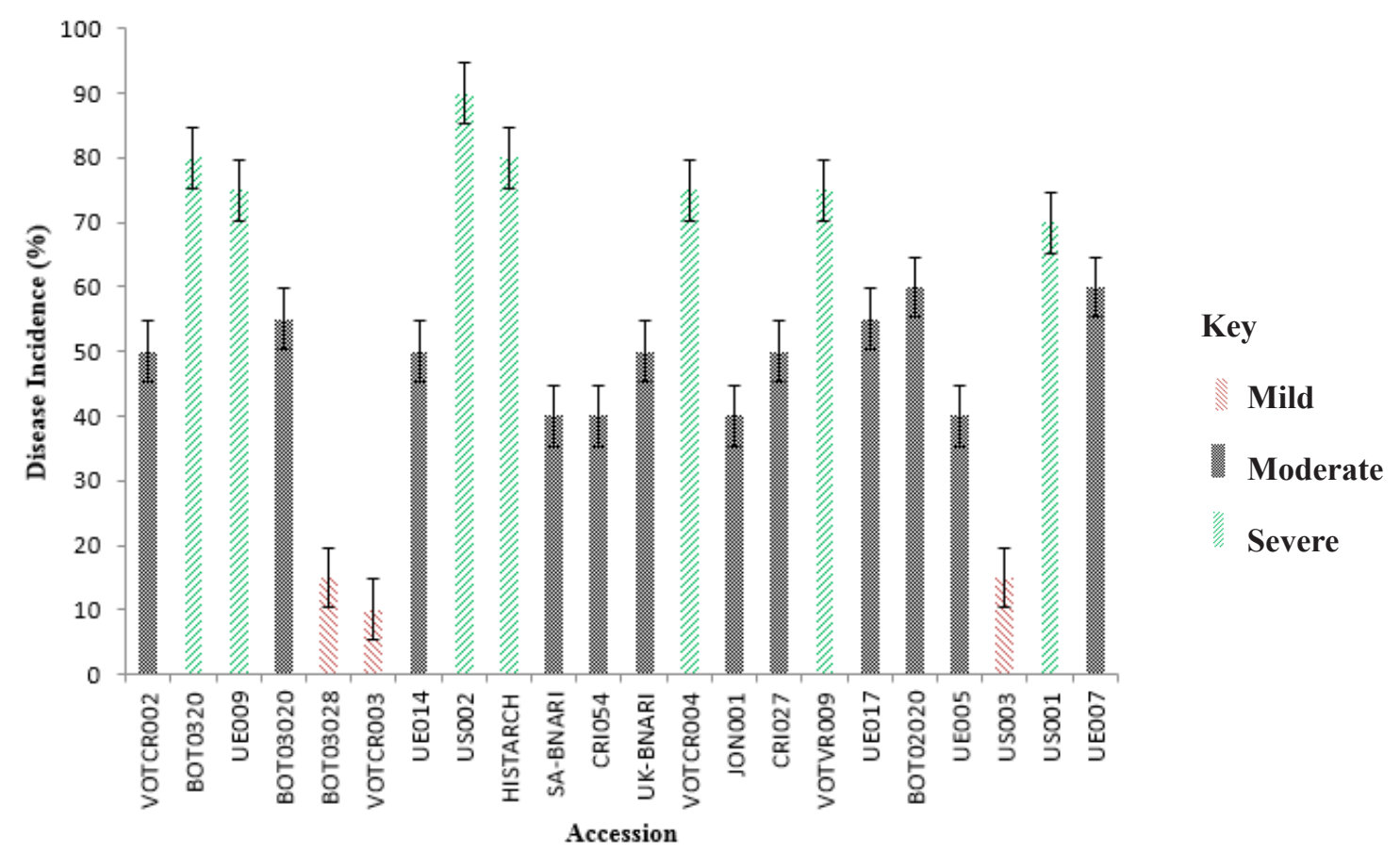

Figure 01. Disease incidence (DI) of 22 accessions of sweet potato at eight weeks after planting.

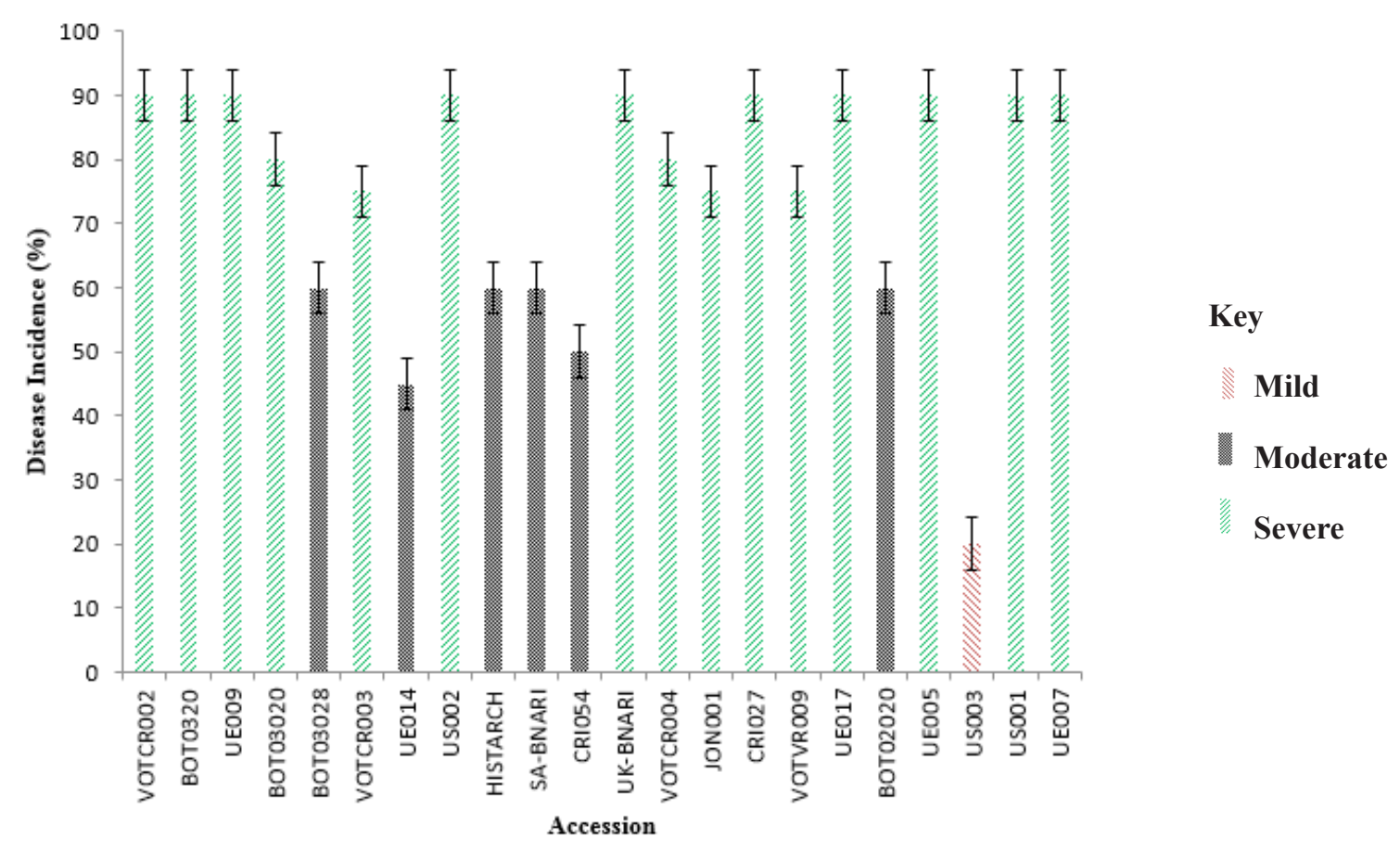

Figure 02. Disease incidence (DI) of 22 accessions of sweet potato at 13 weeks after planting. 
The disease incidence increased from the eighth week to the thirteenth week with all accessions showing symptoms of virus infection (Fig. 02). Most accessions which showed mild and moderate disease incidence at eight weeks after planting increased to severe disease incidence indicating that they were susceptible to virus infection. Accessions JON001, UE005, BOT03020, VOTCR002, UK-BNARI, CRI027, UE017 and UE007 which showed moderate disease incidence of $40,40,50,50,50,55,55$ and $60 \%$ at eight weeks after planting (Fig. 01) increased to severe disease incidence of 75, 90, 90, 90, $90,80,90$ and $90 \%$ respectively indicated by stunted growth, severe leaf distortion and leaf necrosis, by the end of the thirteenth week (Fig. 02). Similarly, VOTCR003 which showed mild disease incidence of $10 \%$ at eight weeks after planting increased to severe disease incidence of $75 \%$ by 13 weeks after planting. The increase in mean DI $(74.55 \%)$ at the end of the thirteenth week could be as a result of increased virus titre due to viral transmission from vectors resulting in significant difference $(p \leq 0.05)$ in all accessions throughout the study period. Although there was a steady increase in DI, accession US003 maintained a low and the least DI of 15 and $20 \%$ in weeks 8 and 13 respectively throughout the study period (Fig. 01 and 02), indicating that it is less susceptible to the viral infection and, therefore, could be planted by farmers depending on tuber size and yield, and can also be used as parent materials for breeding against viruses.

By the end of the thirteenth week, disease symptoms were sometimes absent on young leaves of accessions resulting in a sudden fluctuation in DI in UE014 and Histarch (Fig. 03), suggesting that these accessions were able to recover from the virus infection at some periods in their developmental stages. This is due to plant cell defense mechanisms against diseases known as hypersensitivity resistance and/or systemic acquired resistance. However, in this study, the recovery from the virus complicated the assessment of sweet potato viruses as plants that had recovered were excluded from virus symptomatology diagnosis. Ndunguru and Kapinga (2007) have made similar observations in sweet potato accessions planted in Southern Tanzania. They observed that most young leaves did not show any symptom of virus infection; thus, were excluded in virus assessment.

\section{PCR amplification and detection of Sweet potato leaf curl virus}

The DNA extraction method using Sodium hydroxide $(\mathrm{NaOH})$ produced quality and enough DNA for PCR amplification. Unlike other extraction methods, the $\mathrm{NaOH}$ method was less expensive, very easy and allowed for fast processing of large numbers of samples for virus indexing.

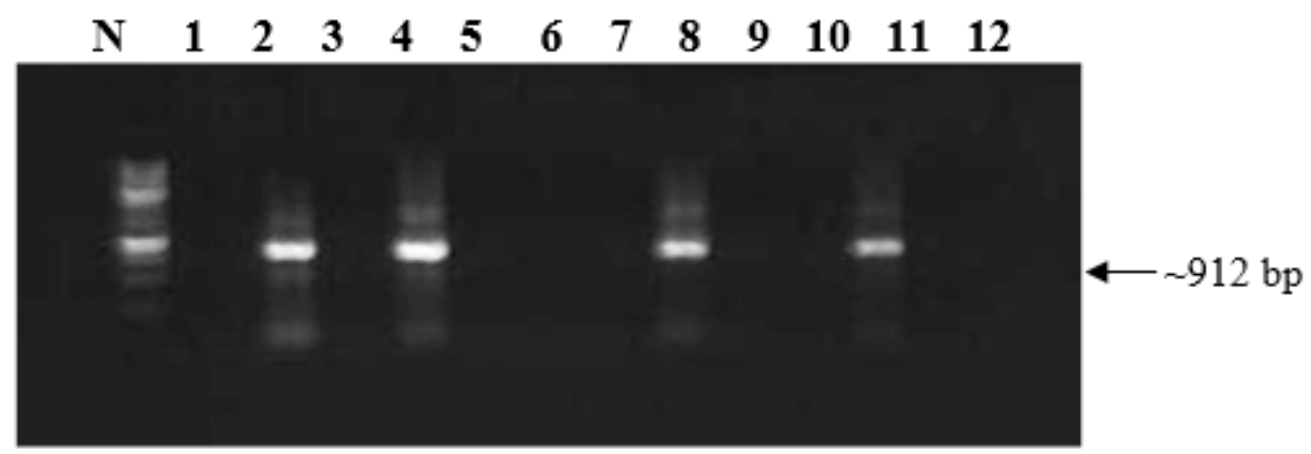

Figure 03. PCR products from genomic DNA of ten accessions of sweet potato using primer pair SPG1/ SPG2. Lane $\mathrm{N}=1 \mathrm{~kb}$ DNA ladder, 1 = UE017, 2 = UK-BNARI, $3=$ UE009, 4 = BOT0320, $5=$ US002, $6=\mathrm{US001}, 7=\mathrm{CRI027,8}=\mathrm{UE007,} 9=$ VOTCR002, $10=\mathrm{UE005}, 11=$ positive control, 12 = negative control. 
Ten accessions which showed severe DI at 13 weeks after planting were assayed for Sweet potato leaf curl virus using PCR techniques with primer pairs SPG1/SPG2 and SPG3/ SPG4. Both primer pairs amplified their corresponding fragments sizes at $\sim 912 \mathrm{bp}$ and $\sim 1148$ bp respectively (Fig. 03 and 04 ) in the coat proteins of the virus in UK-BNARI, BOT0320 and UE007. The positive control was also amplified at corresponding fragment sizes for both primer pairs confirming the presence of the virus. The remaining accessions namely, UE017, UE009, US002, US001, CRI027, VOTCR002, UE005 and the negative controls were not amplified suggesting the absence or probably low titre of the virus in the genomic DNA of the plants.

The Sweet potato leaf curl virus specific primer pair SPG3/SPG4 confirmed the presence of virus in all the infected accessions, as already detected by the geminivirus degenerate primer pair SPG1/SPG2 (Fig. 03 and 04), indicating that both SPG1/SPG2 and SPG3/SPG4 were equally sensitive to the virus in the PCR assay. The primer SPG1/SPG2 has been used to identify several isolates of SPLCV in sweet potato plants due to its high sensitivity as a result of its highly conserved annealing regions of open reading frames $\mathrm{AC} 2$ and $\mathrm{AC} 1$ (Lotrakul et al., 1998). Li et al. (2004) also used the same primers to detect geminivirus in sweet potato accessions collected from different parts of the world and grown in the United States of America.

\section{Thermotherapy coupled with meristem culture to eliminate SPLCV}

The vines of the donor plants developed shoots in the heat chamber one week after planting. Although thermotherapy has been an effective in vitro tool in the reduction of virus population in vegetative propagated plants, it has serious effect on growth and survival of these plants. In this study, only five representing 33.3 $\%$ of UK-BNARI under high temperature survived thermotherapy. This observation may be due to the fact that, the accession is a temperate crop and thrives well under low temperatures but in high temperatures, growth retardation, and in most cases, death becomes predominant. However, unlike UK-BNARI, the thermotherapy did not have any severe effect on growth and survival of UE007 and BOT0320, an observation which could be explained by the fact that these accessions are of tropical origin and could even do well under high temperatures. Surviving shoots were used as explants for meristem culture. In spite of the fact that all the parent plants of the accessions from which vines were taken for thermotherapy showed severe symptoms of virus infection, only the heat treated UE007 accession showed moderate chlorotic spots. The absence of symptoms of virus infection on sweet potato leaves during heat treatment may be due to significant reduction in viral replication by disruption of viral ssRNA and dsRNA synthesis, thereby, reducing virus population during heat treatment.

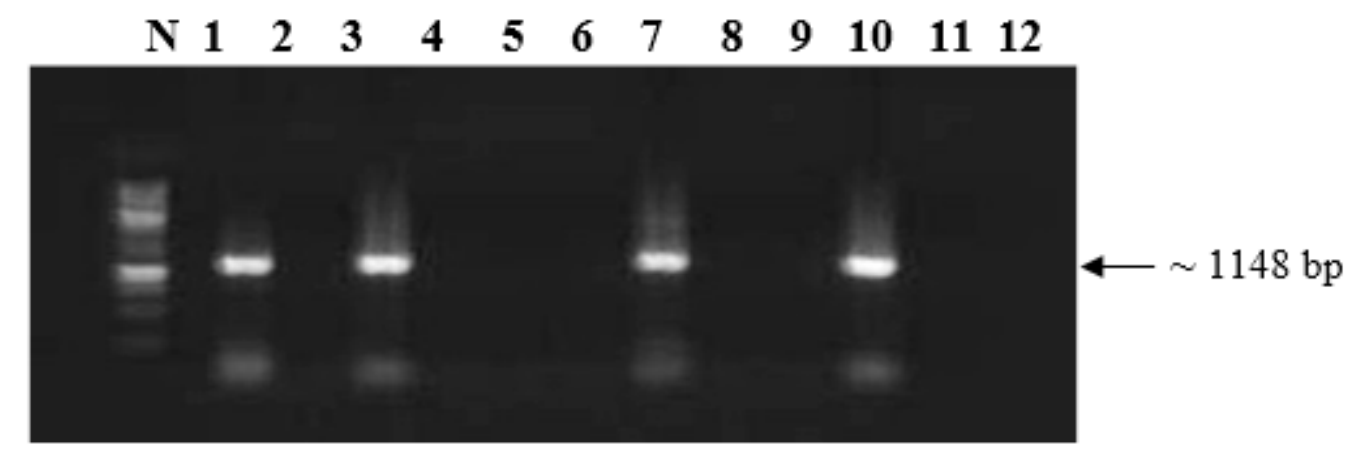

Figure 04. PCR products from genomic DNA of ten accessions of sweet potato using primer pair SPG3/ SPG4. Lane N = 1kb DNA ladder, 1 = UE017, 2 = UK-BNARI, $3=$ UE009, 4 = BOT0320, $5=$ US002, $6=\mathrm{US001}, 7=\mathrm{CRI027,8}=\mathrm{UE007,} 9=$ VOTCR002, $10=\mathrm{UE005}, 11=$ positive control, 12 = negative control. 
All the initiated meristems isolated from young shoot apices of sweet potato cultured on MS basal medium developed shoots within 30 days after culture. For rapid shoot development, the shoots were transferred on basal MS medium supplemented with $0.2 \mathrm{mg} / \mathrm{L}$ BAP, $0.1 \mathrm{mg} / \mathrm{L}$ NAA and $0.1 \mathrm{mg} / \mathrm{L} \mathrm{GA}$. After one month of shoot development, the ${ }^{3}$ leaves of the shoots were harvested for genomic DNA extraction.

The in vitro regenerated plantlets from thermotherapy-meristem tip culture were subjected to PCR assay with primer pairs SPG1/SPG2 and SPG3/SPG4 to detect SPLCV. The virus' DNA was amplified at $\sim 912$ and $\sim 1148$ bp for SPG1/SPG2 and SPG3/ SPG4 respectively in the genomic DNA (Fig. 05 and 06). The positive controls were also amplified at corresponding fragment sizes for both primers. However, the negative controls were not amplified. Of the total number of 21 in vitro regenerated plantlets tested, 11 were cleaned of the virus: three UK-BNARI plantlets representing $42.86 \%$ and four regenerants each of UE007 and BOT0320 representing 57.14\% (Fig. 05 and 06).

Inthepresentstudy, theuseofsmallmeristematic tissue $(0.5 \mathrm{~mm})$ without leaf primordia cultured on basal MS medium resulted in virus elimination in $52.4 \%$ of the regenerants. This observation agrees comparably with that of Ying et al. (2004) which indicated that smaller meristem size is effective in virus eliminate in vegetatively propagated plants. A major advantage of working with such a small explant is its potential for excluding pathogenic organisms that may have been present in the donor plants. Also, according to Kane (2005), active metabolic processes and the production of auxin, cytokinin and phenolamine at the meristematic tissue inhibit virus replication leading to the absence of viruses at the meristematic tissue. Even though $52.4 \%$ of sweet potato plants infected with the virus were cleaned through thermotherapymeristem tip culture, it is of great significance when the effect of virus on yield is considered. Rukarwa et al. (2010) also reported that $77 \%$ of virus-infected plants in Central Uganda were eliminated through meristem tip culture coupled with thermotherapy of $32{ }^{\circ} \mathrm{C}$ for four weeks, and this compares favourably with the result in this work.

The thermotherapy-meristem culture technique could not eliminate the virus in the remaining $47.6 \%$ of the accessions. The exact reason for this observation was not investigated, however, several factors such as size of meristem, strain of infecting virus and duration of heat treatment are known to influence virus elimination from many vegetative propagated plants. The inability of the technique to eliminate the virus in some of the accessions could, therefore, be due to the fact that the size of the meristem was too large or the meristem was taken with leaf primordia which might have haboured the virus. Moreover, it could also be attributed to the fact that the heat treatment was not efficient to enhance virus-induce RNA silencing. In this study, however, the use of small meristematic tissue without leaf primordia cultured on MS basal medium was effective in virus elimination.

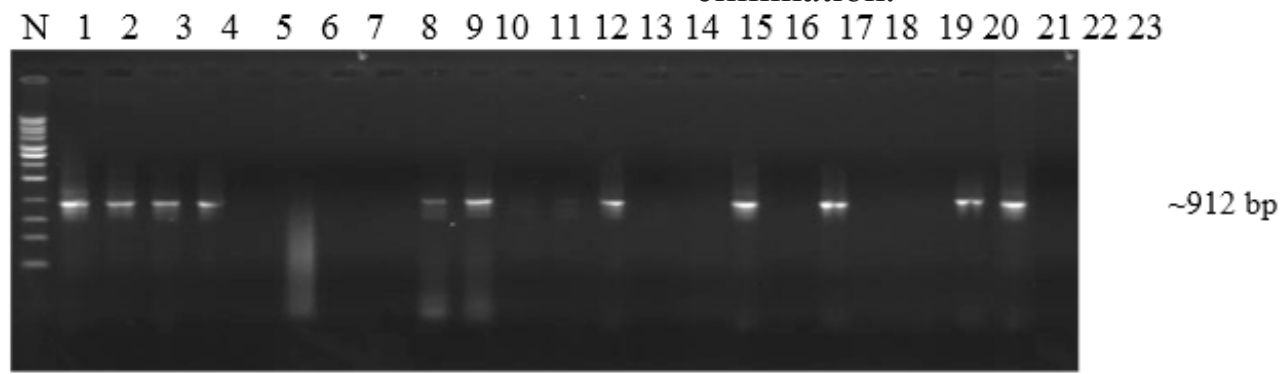

Figure 05. PCR products from genomic DNA with primer pair SPG1/SPG2 of 21 in vitro generated sweet potato plantlets from meristem culture. Lane $\mathrm{N}=1 \mathrm{~kb}$ DNA ladder, 1 - 7 = UK-BNARI, 8 - 14 = UE007, $15-21$ = BOT0320, 22 = Positive control, 23 = Negative control. 


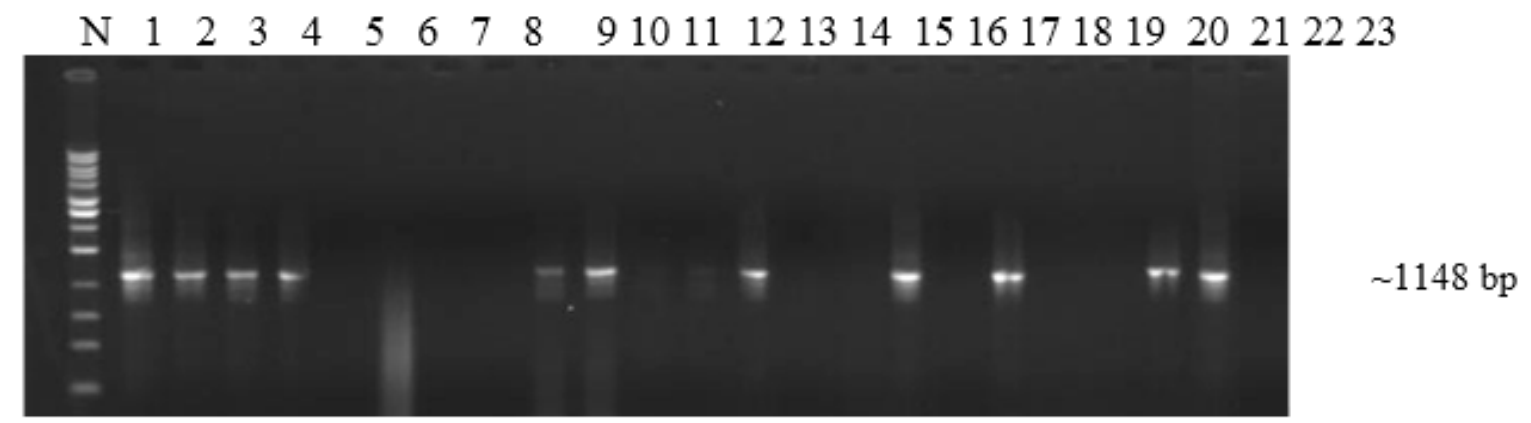

Figure 06. PCR products from genomic DNA with primer pair SPG3/SPG4 of 21 in vitro generated sweet potato plantlets from meristem culture. Lane $\mathrm{N}=1 \mathrm{~kb}$ DNA ladder, 1 - 7 = UK-BNARI, 8 - 14 $=$ UE007, $15-21$ = BOT0320, 22 = Positive control, 23 = Negative control.

\section{CONCLUSIONS}

In this study, viral disease symptoms observed using visual examination showed that all the sweet potato accessions, independent of their origin, expressed virus associated symptoms, indicating susceptibility to sweet potato viruses. The PCR technique with primer pairs SPG1/SPG2 and SPG3/SPG4 was found to be an effective and reliable tool for virus detection as it revealed the presence of SPLCV in the sweet potato accessions.

Traditional thermotherapy at $35{ }^{\circ} \mathrm{C}$ for four weeks coupled with meristem-tip culture eliminated SPLCV from in vitro regenerated sweet potato samples. It is, therefore, clear that traditional thermotherapy coupled with meristem tip culture can be used to produce virus-free planting materials for farmers or germplasm for future breeding programmes.

\section{ACKNOWLEDGEMENT}

We are grateful to Prof. Kenneth Ellis Danso, Director, Biotechnology and Nuclear Agriculture Research Institute (BNARI) of the Ghana Atomic Energy Commission (GAEC) for allowing us to use his facilities and also supervising this work.

\section{REFERENCES}

El Far, M. M. M. and Ashoub, A. (2009). Utility of thermotherapy and meristem tip for freeing sweet potato from viral infection, Australian Journal of Basic and Applied Sciences. 3(1): 153-159.

Fuentes, S. (2010). Sweet potato virus indexing for International Potato Centre (CIP), HolettaEthiopia. 1-18.

Ghosh, D. K. and Aglave, B. (2007). Simultaneous detection of one RNA and one DNA viruses from naturally infected citrus plants using duplex PCR technique, Current Science. 94: 1314-1319.

Kane, M. E. (2005). Shoot culture procedure. In: Plant Development and Biotechnology. (Trigiano, R. N. and Gray, D. J. Eds.). CRC Press, Boca Raton, London, New York, Washington D.C. 145-157.

Li, R., Salih, S. and Hurtt, S. (2004). Detection of geminiviruses in sweet potato by polymerase chain reaction, Plant Disease. 88: 1347-1351. 
Lotrakul, P., Valverde, R. A., Clark, C. A., Sim, J. and De La Torre, R. (1998). Detection of a Geminivirus infecting sweet potato in the United States, Plant Disease. 82: 1253-1257.

Murashige, T., Skoog, F. (1962). A revised medium for rapid growth and bioassays with tobacco tissue cultures, Plant Physiology. 15: 473-497.

Ndunguru, J. and Kapinga, R. (2007). Viruses and virus-like diseases affecting sweet potato subsistence farming in Southern Tanzania, Africa Journal of Agriculture Research. 2(5): 232-239.

Ndunguru, J., Kapinga, R., Sseruwagi, P., Sayi, B., Mwanga, R., Tumwegamire, S. and Rugutu, C. (2009). Assessing the Sweet potato virus disease and its associated vectors in northwestern Tanzania and central Uganda, African Journal of Agricultural Research. 4(4): 334-343.

Njock, T. E. and Ndip, R. N. (2007). Limitation in detecting Africa Cassava Mosaic Geminivirus in lignified tissue of cassava stems, Africa Journal of Biotechnology. 6(20): 101-108.

Opiyo, S. A., Ateka, E. M., Owuor, P. O., Manguro, L. O. A. and Miano, D. W. (2010). Development of multiplex PCR technique for simultaneous detection of SPFMV and SPCSV, Journal of Plant Pathology. 92(2): 363-366.

Qu, F., Ye, X. H., Hou, G. C., Sato, S., Clemente, T. E. and Morris, T. J. (2005). RDR6 has a broadspectrum but temperature-dependent antiviral defense role in Nicotiana benthamiana, Journal of Virology. 79: 15209-15217.

Rukarwa, R. J., Mashingaidze, A. B., Kyamanywa, S. and Mukasa, S. B. (2010). Detection and elimination of sweet potato viruses, African Crop Science Journal. 18(4): 223-233.

Tairo, F., Kullaya, A. and Valkonen, J. P. T. (2004). Incidence of viruses infecting sweet potato in Tanzania, Plant Disease. 88: 916-920.

Wang, H., Qi, M. and Cutler, A. J. (1993). A simple method of preparing plant samples for PCR, Nucleic Acids Research. 21(17): 4153-4154.

Wang, Q. C., Cuellar, W. J., Rajamäki, M. L., Hiraka, Y. and Valkonen, J. P. T. (2008). Combined thermotherapy and cryotherapy for efficient virus eradication: Relation of virus distribution, sub-cellular changes, cell survival and viral RNA degradation in shoot tips, Molecular Plant Pathology. 9: 237-250.

Woolfe, J. A. (1992). Sweet potato: An untapped food resource. Cambridge University Press, New York. pp. 142-145.

Ying, Q. D., Ying, Z. and Davenport, L. T. (2004). Meristem-tip culture boosts yield of sweet potato cv. Picadita in South Florida, Proceedings of the Florida State Horticultural Society. 117: 70-76. 